\title{
THE UNAUTHORIZED PRACTICE OF LAW BY LAYMEN AND LAY ASSOCIATIONS
}

The problemn of unauthorized practice of the law is a problem of using the processes of the law to define and protect a inonopoly. ... If laymen can do some jobs better or more cheaply and rapidly than lawyers, and they are specialized jobs, with articulate interests behind them, can a lawyer's monopoly-by law-stand up? ${ }^{1}$

When completing a sale of real property, a real estate broker will often save the buyer and seller the time and expense of hiring an attorney by drafting or preparing the deed of transfer himself. Similarly, an "estate planner" or insurance salesman will frequently advise a client or potential client concerning the effects of the federal estate tax on a particular testamentary provision in the client's will. In other cases, a labor union may hire an attorney to represent or advise the individual members of the union on their personal legal problems; or an accountant may represent a taxpayer in proceedings before the Treasury Department.

These are only a few examples of legal activities which have been undertaken by laymen or associations, and which liave been attacked by various national, state, or local bar associations and enjoined by the courts as unauthorized practice of law. ${ }^{2}$ The bar associations generally justify their action on the theory that the public should be protected from unqualified and incompetent practitioners and that the action is necessary to protect the dignity of the judicial process. ${ }^{3}$ The court's authority to enjoin ${ }^{4}$ the activities complained of may be based on legislative enactinents, ${ }^{5}$, canons of ethics, ${ }^{6}$ or the court's inherent power to regulate the

1 Llewellyn, The Bar's Troubles, and Poultices-and Cures?, 5 Law \& Contenp. Pros. 104, 107 (1938).

2 Cases involving the question whether certain activities constitute the unauthorized practice of law have also arisen when a party refuses to pay for services rendered, contending that they were rendered under an illegal contract because the person performing the services was engaging in the unauthorized practice of law. See, e.g., Agran v. Shapiro, $127 \mathrm{Cal}$. App. 2d Supp. 807, 273 P.2d 619 (1954) (accountant denied recovery of fee for legal tax services rendered).

The history of and the techniques used in the organized bar's campaign against the unauthorized practice of law are discussed in 48 A.B.A.J. 99, 112-14 (1962).

3 See, e.g., West Virginia State Bar v. Earley, 144 W. Va. 504, 527-28, 109 S.E.2d 420, 435-36 (1959). For an excellent discussion of the role and activities of a state bar committee on the unauthorized practice of law, see 40 CAL. S.B.J. 615 (1965).

${ }^{4}$ There are various remedies available to combat the unauthorized practice of law. These include injunction, criminal prosecution, contempt of court, and quo warranto. See generally Note, 62 CotuM. L. REv. 501 (1962).

5 See, e.g., NAACP v. Patty, 159 F. Supp. 503, 530-34 (E.D. Va. 1958), in which the constitutionality of such statutes was challenged.

${ }^{6}$ See, e.g., NAACP v. Harrison, 202 Va. 142, 156-57, 116 S.E.2d 55, 67-68 (1960). For a discussion of the force and effect of these canons in the courts and in bar association 
practice of law. ${ }^{\top}$

Despite the existence of criminal statutes prohibiting the unauthorized practice of $\mathrm{law}^{8}$ and treaties between bar associations and various occupational groups defining those activities that members of these occupations may or nuay not engage in, ${ }^{9}$ laymen nonetheless continue to perform legal services. Thus the courts are frequently called upon to settle disputes concerning outright violations of the statutes or treaties, activities which are imphedly though not specifically prohibited by the statutes or treaties, or conduct which falls within their penumbra. In most instances, the courts have a wide discretion in determining which activities should be enjoined and which should be permitted to continue. ${ }^{10}$ Unfortunately, the courts have often limited their analyses to the interests of the lay occupational groups or the bar associations involved in the disputes, ignoring the public need for competent, low-cost legal services.

The public, particularly in the lower- and middle-income levels, has an unfilled need for legal services. ${ }^{11}$ As income levels rise and society

proceedings, see Drnnker, Legar Etrucs 30, 32 (1953). The American Bar Association Canons of Ethics are commended to members of the California State Bar. Rule 1, Rules of Professional Conduct, State Bar of California, authorized by Cax. Bus. \& Prof. Code $\S 6076$. [hereinafter cited as Rules of Professional Conduct.]

7 See, e.g., In re Baker, 8 N.J. 321, 334-35, 85 A.2d 505, 511-12 (1951); Richmond Ass'n of Credit Men v. Bar Ass'n of City of Richmond, 167 Va. 327, 335-36, 189 S.E. 153, 157 (1937). See generally Comment, 28 U. CHI. L. REv. 162 (1960).

8 See, e.g., Cax. Bus \& Prof. CODE $\$ \$ 6126-27$. All the state and the District of Columbia statutes relating to the unauthorized practice of law are compiled in AMrerrcas BAR FOUNDAiton Project on the UNauthorized Practice of LaW, Unauthorized Practice Statute Book (1961).

9 See, e.g., 3 Martindale \& Hubbeil, LAw Directory 189A (1966). These statements of principles or treaties are analogous to work assignment or jurisdictional agreements between labor unions.

10 Indeed, many courts have claimed that their power to regulate the practice of law is exclusive and that legislative enactments merely supplement this jurisdiction. See, e.g., In re Opimion of the Justices, 279 Mass. 607, 611, 180 N.E. 725, 727 (1932). See generally, Dowling, The Inherent Power of the Judiciary, 21 A.B.A.J. 635 (1935); Comment, 28 U. CEII. L. REv. 162 (1960).

11 Numerous commentators have reached this conclusion. See Brown, Law Offices for Middle-Income Clients, 40 CAI. S.B.J. 720 n.1 (1965). Moreover, statistics from various surveys indicate that few middle or lower-middle income class persons with legal problems consult an attorney. Committee Report on Group Legal Services, 39 CAI. S.B.J. 639, 652-59 (1964). The results of these surveys have been conveniently charted. Carlin \& Howard, Legal Representation and Class Justice, 12 U.C.L.A.L. REv. 381, 383 (1965). The California State Bar Committee on Group Legal Services has proposed an extensive survey to discover, among otler things, how often members of the public actually use the services of an attorney, how often they fail to consult an attorney because they do not recognize the existence of a legal problem, and how much difficulty they have in finding an attorney experienced in the type of problem that is of concern. Committee Report on Group Legal Services, supra at 729-32. 
becomes more complex, the government, through regulation and taxation, plays a greater role in the hives of all persons, and more persons are confronted with legal problems requiring expert assistance and advice. ${ }^{12}$ These persons often hesitate to seek the aid of an attorney because they are unable to pay the legal fees or because the matter cannot profitably be handled by an attorney. Moreover, many persons are unaware of their legal rights and thus do not recognize the need for the services of an attorney. Many do not know where to locate an attorney they can trust. ${ }^{13}$

Frequently lay practitioners fill this gap by providing readily accessible and low-cost services to the public. ${ }^{14}$ In response, the bar associations have done little to compete with these lay practitioners and have failed to provide the needed services at comparable costs. Rather, the organized bar has conducted extensive campaigns to halt these lay activities. ${ }^{15}$ The result has been a struggle between power groups, ${ }^{16}$ and frequently the courts are called on to settle the dispute. Too often the courts have upheld canons of ethics of the legal profession which fail to reflect both public and professional interests; too often they have enjoined lay activities without considering whether lawyers will perform the needed services adequately and at a reasonable cost.

This Comment seeks to describe, analyze, and apply the criteria which the courts should consider in deciding whether legal practices by laymen should be enjoined or otherwise prohibited. First, these criteria are defined and their rationale and purpose are examined. Next, these criteria are applied to several situations in which laymen are presently performing legal services for the public despite bar association and legislative attempts to discourage this conduct. ${ }^{17}$ Since the

12 See Schwartz, Foreword: Group Legal Services in Perspective, 12 U.C.L.A.L. Rev. 279, 295 (1965).

13 See Cheatham, Availability of Legal Services: The Responsibility of the Individual Lawyer and of the Organized Bar, 12 U.C.L.A.L. REv. 438 (1965).

14 See Carin, Lawyers on Ther OWN 142-45 (1962); Llewellyn, supra note 1, at $112-13$.

${ }^{15} \mathrm{~A}$ convincing argument has been made that the responsibility for providing legal services to all persons belongs to the organized bar. See Cheatham, supra note 13.

18 The occupational groups have charged: "They're after us because there are too many lawyers and a dearth of business for them .... The lawyers have a union, and they're simply trying to carve out more business for that union." Wall Street J., March 29, 1961, p. 1, col. 6. The organized bar has answered: "[T] he primary purpose of this Committee is to protect the public from the problems that can arise when legal advice is received from one not learned in all phases of the law, one not giving impartial advice ... and one not subject to any professional discipline. It is not for the purpose of protecting the lawyers' income that this Committee exists, as so many seem to think." 40 CAL. S.B.J. 615 (1965).

17 The purpose of this Comment is not to designate specific activities which con- 
criteria which are relevant or applicable will vary from case to case, no rules of law or conclusions are formulated. Rather, it is suggested that the courts weigh the competing interests and consider eacl case separately.

\section{CRITERIA}

\section{A. Competency in Handling the Matter}

All states have character and educational or legal training requirements whicls all persons who wish to practice law must meet. ${ }^{18}$ In California, for example, the applicant for practice must have graduated from an approved law school; or he must prove that he has studied law diligently for a period of at least four years in a. law school, under the supervision of an experienced member of the bar or a judge, or through a correspondence course. ${ }^{19}$ The objective of such legal training is not only to acquaint the prospective attorney with the substantive areas of the law, but also to develop his powers of analysis, ${ }^{20}$ to familiarize him with basic legal skills, ${ }^{21}$ and to enlighten him as to his professional responsibility toward the pulbhic. ${ }^{22}$

Few lay practitioners have fulfilled all of these training or educational requirements, but many non-lawyers who work in specialty fields have acquired a greater competence in their particular field than the lawyer who is a general practitioner. Moreover, lay specialists are often able to offer more efficient and less expensive service to their clients. ${ }^{23}$ Perhaps the greatest deficiency of lay speciahists is their inabihty to spot legal problems outside the area of their particular competence. For example, it is unlikely that an accountant would be able to spot subtle legal

stitute the practice of law, but to point out dangers which arise when laymen or lay agencies are allowed to handle legal or semi-legal problems. Cases defining activities which constitute the practice of law are collected in Annots, 151 A.L.R. 781 (1944); 125 A.L.R. 1173 (1940); 111 A.L.R. 19 (1937). See generally, 26 FordHaMr L. Rev. 163 (1957); Note, 12 Syracuse L. Rev. 500 (1961).

18 See DRINKER, LEGAI ETHICS 20 (1953).

19 See CaI. Bus. \& Pror. Code $\$ 6060(\mathrm{~g})$. Cf. $\$ 6050$ (c) (moral character).

20 See Harno, Legai Eddcation in the United States 64 (1953).

21 Id. at 172-76. The author indicates that many law schools have neglected this objective. $I d$. at $147-55$.

22 Id. at 155-60. Basically, the applicant for practice should be aware that legal skills must be directed toward other than personal ends.

${ }^{23}$ See Llewellyn, supra note 1, at 111-13. "A title company simply can more effectively gather records than the ordinary lawyer can; and over the years it can therefore organize to do a job both more quickly, more effectively and more cheaply; it can issue insurance which the ordinary lawyer cannot, against its own error or negligence. It offers a better social machinery for the job." Id. at 112 . 
questions outside the area of the tax law. ${ }^{24}$ In many routine matters, however, the absence of a general legal education would be relatively unimportant compared to the low cost of the services offered to the public.

\section{B. Elements of the Attorney-Client Relationship ${ }^{25}$}

\section{Strict Fiduciary Standard}

An attorney is held to a strict fiduciary standard in his relations with his client. ${ }^{26}$ Thus all the actions of an attorney should directly benefit his chent; any dealings, agreements or contracts, other than original contracts of retainer, between a lawyer and his client should be carefully scrutinized $^{27}$ and are presumptively invalid. ${ }^{28}$ This fiduciary duty may extend beyond the lawyer's immediate clients to persons who rely upon him for information. ${ }^{29}$ Furthermore, an attorney cannot receive remuneration or consideration from persons other than his client without full disclosure and consent; ${ }^{30}$ nor can he purchase any interest in the subject matter of any litigation which he is conducting. ${ }^{31}$ The attorney has a duty to settle cases when it would be advantageous to the client, ${ }^{32}$ and a clause in a retainer agreement prohibiting the client from settling without the attorney's permission is invalid..$^{33}$

The importance of a strict fiduciary duty or the absence of such a standard in determining whether certain activities should be enjoined

24 See Bittker, Professional Responstimity and Federat Tax Practice 38-39 (1965) [hereinafter cited as BITTKER], wherein the author discusses three recent federal tax cases which were decided on grounds unrelated to tax law.

${ }^{25}$ As to when this relationship begins, see Keenan v. Scott, 64 W. Va. 137, 61 S.E. 806 (1908).

${ }^{26}$ A.B.A. Canon 11 provides: "The lawyer should refrain from any action whereby for his personal benefit or gain he abuses or takes advantage of the confidence reposed in him by his client.

"Money of the client or collected for the chient or other trust property coming into the possession of the lawyer should be reported and accounted for promptly, and should not under any circumstances be commingled with his own or be used by him." See generally, DrINEER, Legat ETHICS 89-96 (1953).

${ }^{27}$ See, e.g., In the Matter of Howell, 215 N.Y. 466, 472, 109 N.E. 572, 574 (1915).

28 See, e.g., Bell v. Ramirez, 299 S.W. 655, 658 (Tex. Civ. App. 1927).

20 See Drmiker, Legat Etwics 92 (1953).

30 A.B.A. Canon 38 provides: "A lawyer should accept no compensation, commissions, rebates or other advantages from others without the knowledge and consent of his client after full disclosure."

31 A.B.A. Canon 10 provides: "The lawyer should not purchase any interest in the subject matter of the bitigation which he is conducting." Cf. Rule 6, Rules of Professional Conduct.

32 A.B.A. Canon 8, in part, provides: "Whenever the controversy will admit of fair adjustment, the client should be advised to avoid or to end the hitigation."

33 See, e.g., In re Snyder, 190 N.Y. 66, 70-71, 82 N.E. 742, 743-44 (1907). 
as the unauthorized practice of law will, of course, depend upon the circumstances of each case. Many lay practitioners, such as trust companies, are subject to fiduciary standards. In other cases such a standard may be an irrelevant or unimportant consideration in determining whether particular lay activities should be enjoined. In every case where a lay body performing legal services is not subject to a strict fiduciary duty, the court should consider the likelihood that the absence of such a duty will tempt the practitioner to benefit himself wrongfully or injure his customer, and weigh this danger against the value of the services rendered.

\section{Duty Not to Represent Conflicting Interests}

An attorney must avoid situations where there is a possibility that his chent's interests will conflict with his own interests or with those of a present or former chent, ${ }^{34}$ or where such a conflict is likely to develop. ${ }^{35}$ The test is whether, in faithfully representing a client, the attorney will be required to take action which will injure himself or any other client, or to use information acquired from another client. ${ }^{36}$ For example, one representing $B$ against $C$ may not at the same time represent $C$ against $D .^{37}$

A corollary of this mandate is that the attorney must maintain a

34 A.B.A. Canon 6 provides: "It is the duty of a. lawyer at the time of retainer to disclose to the client all the circumstances of his relations to the parties, and any interest in or connection with the controversy, which might influence the client in the selection of counsel.

"It is unprofessional to represent conflicting interests, except by express consent of all concerned given after a full disclosure of the facts. Within the meaning of this canon, a lawyer represents conflicting interests when, in bchalf of one client, it is his duty to contend for that which duty to another client requires him to oppose.

"The obhgation to represent the client with undivided fidehty and not to divulge his secrets or confidences forbids also the subsequent acceptance of retainers or employment from others in matters adversely affecting any interest of the chient with respect to which confidence has been reposed." See Rules 4 and 7, Rules of Professional Conduct. See generally, DrinkER, Legax Ethics 103-30 (1953).

35 Thus an attorney who represents $X$, a guest, in a neghigence suit against the insured driver for injuries should not also represent $Y$, another guest, if $X$ is also the owner of the automobile and could be hable to $Y$. See DrankER, Legar ETHrcs 105 n.29 (1953).

${ }^{36}$ See In re Boone, 83 Fed. 944, 952-53 (N.D. Cal. 1897).

37 Normally, insurance pohicies contain cooperation clauses giving the insurer the right to defend against any suit. When the persons involved in an accident are insured by the same company, obvious problems of conflicting interests arise-the insurance company would have a pecumiary interest in conducting the hitigation so that neither party would recover from the other. In such a case, one court refused to enforce the cooperation clause and held that the insurer was liable for the costs incurred by one party in employing an independent attorney to defend him against the other party. OMorrow v. Borad 27 Cal. 2d 794, 167 P.2d 483 (1946). Cf. Czaphcki v. The S.S. Hoegh Silvercloud, 351 U.S. 525 (1956). See generally, DrRTKER, Legar, ETHICS 114-18 (1953); Annot., 163 A.L.R. 899 (1946). 
direct relationship with his client; no lay agency-personal or corporate -should intervene between the lawyer and his client. ${ }^{38}$ Thus an association or corporation may not hire an attorney to represent its inembers in their personal matters, ${ }^{39}$ nor may an attorney employed by a lay organization perform legal services for the organization's customers. ${ }^{40}$

The rationale and purpose of these rules are clear-an attorney is licensed to represent persons in their legal activities and the person receiving these services is entitled to the attorney's undivided allegiance. The lawyer is his client's mouthpiece. Such allegiance is not possible if the attorney represents another client with conflicting interests, or if the attorney is employed and paid by an orgamization separate from his client.

Again, in controlling the unauthorized practice of law, the importance which the courts should give to this element of the attorney-client relationship depends upon the particular circumstances. For example, when a real estate broker prepares a deed conveying real property from the seller, whom he represents, to the buyer, the broker is obviously performing services for persons with conflicting interests. ${ }^{41}$ On the other hand, the interests of an association employing an attorney and the members whom the attorney represents may be nearly identical. This would be the case, for example, when a labor union retains counsel to represent its members. ${ }^{42}$

\section{Protection of Confidential Communications}

Since the attorney's primary duty is to his client, he cannot voluntarily divulge confidential information received from the client. ${ }^{43}$ The only

38 A.B.A. Canon 35 provides in part: "The professional services of a lawyer should not be controlled or exploited by any lay agency, personal or corporate, which intervenes between chent and lawyer .... A lawyer's relation to his client should be personal, and the responsibility should be direct to the client. Charitable societies rendering aid to the indigents are not deemed such intermediaries.

"A lawyer may accept employment from any organization, such as an association, club or trade organization, to render legal services in any matter in which the organization, as an entity, is interested, but this employment should not include the rendering of legal services to the members of such an organization in respect to their individual affairs."

39 See, e.g., People ex rel. Courtney v. Association of Real Estate Taxpayers, 354 IIl. 102, 110, 187 N.E. 823, 826 (1933); but see Vitaphone Corp. v. Hutchinson Amusement Co., 28 F. Supp. 526 (D.C. Mass. 1939).

40 See A.B.A. Canon 35, supra note 38. A.B.A. Canon 47 provides: "No lawyer shall permit his professional services, or his name, to be used in aid of, or to make possible, the unauthorized practice of law by any lay agency, personal or corporate." $C f$. Kentucky State Bar v. First Fed. Sav. \& Loan Ass'n, 342 S.W.2d 397, 398 (Ky. 1960).

41 See, e.g., Chicago Bar Ass'n v. Quinlan \& Tyson, Inc., 53 Ill. App. 2d 388, 203 N.E.2d 131 (1964).

42 See, e.g., Brotherbood of R.R. Trainmen v. Virginia State Bar, 377 U.S. 1 (1964). 43 A.B.A. Canon 37 provides in part: "It is the duty of a lawyer to preserve his client's 
exceptions are an announcement of a proposed crime or fraud ${ }^{44}$ and communications which were not intended to be privileged, as, for example, when the other party to the case or a third person is present when the communication is made. ${ }^{45}$ If the lawyer is to represent his client adequately he must know all the facts, and the client will not reveal prejudicial facts unless he is certain that his lawyer cannot be compelled to disclose these facts. Therefore, such commumications are protected by the attorney-client privilege. ${ }^{46}$

In contrast, lay practitioners are not subject to a restriction against voluntary divulgence of confidential information disclosed to them by their customers, and their customers are not protected against compulsory disclosure of such information. ${ }^{47}$ The courts may, therefore, consider this deficiency in deciding whether, under certain circumstances, legal activities undertaken by laymen should be enjoined. In some cases, of course, this criterion will be irrelevant or unimportant, but frequently it will be a key factor. For example, an accountant or layman engaging in estate planning or tax work could be required to divulge information to the Treasury Department which would result in increased taxes to the customer. ${ }^{48}$ Similarly, since the attorney's primary duty is to his client,

confidences. This duty outlasts the lawyer's employment, and extends as well to his employees; and neither of them should accept employment which involves or may involve the disclosure or use of these confidences, either for the private advantage of the lawyer or his employees or to the disadvantage of the client, without his knowledge and consent, and even though there are other available sources of such information. . . .

"If a lawyer is accused by his chent, he is not precluded from disclosing the truth in respect to the accusation. The announced intention of a client to commit a crime is not included within the confidences which he is bound to respect. He inay properly inake such disclosures as may be necessary to prevent the act or protect those against whom it is threatened." See Cal. Evidence Code § 955; CaL. Bus. \& Prof. Code § 6068(e). See generally, Drminer, Legal Emancs 1.31-39 (1953); McCoranck, Evmence 196 (1954).

44 See, e.g., Ott v. State, 87 Tex. Crim. 382, 385, 222 S.W. 261, 262-63 (1920) (husband consulted a lawyer as to probable punishment if he killed his wife); Cax. Evinence Code $\S 956$.

45 Other party to action: See, e.g., Ver Bryck v. Luby, 67 Cal. App. 2d 842, 844, 155 P.2d 706, 707 (1945); CaI. EvmEncE Code § 962. Third person: See, e.g., Himmelfarb v. United States, 175 F.2d 924, 938-39 (9th Cir. 1949) (presence of accountant destroyed privilege); CaL. Evimence Code $\S 952$. Other exceptions are stated in CaI. Evimence Code $\$ \S 958-61$.

46 See Annesley v. Earl of Anglesca, 17 Hower工, State Trass 1129, 1225, 1241 (1743), quoted in 8 WIGMORE, EvmENCE \& 2291 (3rd ed. 1940). The privilege includes acts and other forms of communication as well as words. See, e.g., City \& County of San Francisco v. Superior Court, 37 Cal. 2d 227, 235, 231 P.2d 26, 30 (1951).

47 But see, People v. Barker, 60 Mich. 277, 297, 27 N.W. 539, 546 (1886) (confession to detective pretending to be an attorney); CAI. EvIDEnCE CODE $\$ 950$.

48 In California, the privilege includes advice given by the lawyer in the course of the attorney-client relationship. See CaI. Evmence Code $\S 952$. Thus, for example, if an attorney advised his client to inake certain gifts to reduce potential estate taxes and the chent died within three years of making the gifts, the attorney could not be compelled to testify as to the purpose for making the gifts. See CaI. EvIDENCE CODE $\$$ 953(c). This 
an attorney employed by an association that provides legal services to the public would have a duty to disclose to the association information prejudicial to a person for whom the attorney performed legal services. ${ }^{49}$

\section{Disciplinary Proceedings}

A lawyer not only is hable to his client for negligence or fraud, ${ }^{50}$ but also is subject to disciplinary proceedings for failure to meet professional standards. These proceedings are not imstituted to enforce private remedies, but to protect the public and the courts against an attorney who cannot be trusted to advise and act for clients, or whose presence as an attorney would impair the dignity of the court. ${ }^{51}$ Complaints against an attorney for such misconduct can be filed by anyone. Usually the state bar association has a grievance committee which las the authority to hear complaints and make recommendations to the courts. ${ }^{52}$ In addition, the courts on their own motion can discipline lawyers for professional misconduct, provided the attorney charged is given adequate notice and an opportunity to be heard in his own defense..$^{53}$

would not be the case if a non-lawyer had given the advice and the gifts would, therefore, be taxed as having been made in contemplation of death. See Treas. Reg. $\S 20.2035-1$ (c) (1) ; Falsone v. United States, 205 F.2d 734 (5th Cir. 1953); Himmelfarb v. United States, 175 F.2d 924, 938-39 (9th Cir. 1949); note 119 infra.

49 A.B.A. Canon 8, in part, provides: "A lawyer should endeavor to obtain full knowlege of his client's cause before advising thereon, and he is bound to give a candid opinion of the merits and probable result of pending or contemplated hitigation. ..." As a practical matter, of course, an attorney would divulge the information to his permanent employer even if he was under no ethical obligation to do so.

50 "The general rule with respect to the liability of an attorney for failure to properly perform his duties to his client is that the attorney, by accepting employment to give legal advice or to render other legal services, imphedly agrees to use sucl skill, prudence, and diligence as lawyers of ordinary skill and capacity commonly possess and exercise in the performance of the tasks which they undertake ... . The attorney is not hable for every mistake he may make in his practice; he is not, in the absence of an express agreement, an insurer of the soundness of his opinions or of the validity of an instrument that he is engaged to draft; and he is not liable for being in error as to a question of law on which reasonable doubt may be entertained by well-informed lawyers." Lucas v. Hamm, 56 Cal. 2d 583, 591, 15 Cal. Rptr. 821, 825 (1961) (attorney not liable for violation of rule against perpetuities). It is not an easy matter to recover damages from an attorney for his alleged negligence. An injured party inust not only neet the burden of proof; he must also find an attorney willing to handle the action. See Wade, The Attorney's Liability for Negligence, 12 VAND. L. Rev. 755, 774 (1959).

It should be noted, however, that reluctance of plysicians to testify in medical malpractice suits has not proven to be an insurmountable barrier against bringing such suits. See generally Louiserl \& Writuams, Trial of Medical MaIpractice Cases \$§ 1.05-.06, 7.08, 14.01-.03 (1965).

51 Cases are collected and classified according to type of misconduct in DRnKER, LEGAT ETHICS 304-08 (1953).

62 See, e.g., Car. Bus. \& Prof. Code $\$ \S 6078 ; 6081 ; 6086.5$.

53 See, e.g., Car. Bus. \& Prof. Code $\S 6100$; Randall v. Brigham, 74 U.S. (7 Wall.) 523, 539-40 (1868); State v. Peck, 88 Conn. 447, 452-54, 91 Atl. 274, 276-77 (1914). 
In designating activities which can be performed by laymen and those which must be performed by attorneys, the courts should consider whether the lay practitioner is subject to disciplinary restraints which go beyond private forms of redress. In many cases where administrative discipline is absent, the possibility of a private remedy may be ineffective in controlling lay misconduct, either because the particular misconduct involved does not give rise to a cause of action ${ }^{54}$ or because the limited recovery possible would not discourage further misconduct. ${ }^{55}$ On the other hand, many lay practitioners such as accountants are subject to administrative disciplinary action. ${ }^{58}$ When a lay body such as a corporation provides legal services to members of the public through its own attorneys, the attorneys will, of course, be subject to the same discipline as other attorneys.

\section{Solicitation of Business and Public Awareness of the Need for Legal Services}

Since the admimistration of justice is undertaken primarily for the public good and not for private profit, ${ }^{\mathrm{bT}}$ and since stirring up hitigation is not in the public interest, attorneys may not advertise their services nor solicit busmess. ${ }^{58}$ If individual lawyers could advertise and solicit business without restriction, professional reputation would depend upon the effectiveness of an advertising campaign rather than the quality of the services performed. Moreover, attorneys might be tempted to use improper means to fulfill excessive claims in advertiseinents. ${ }^{50}$

Lay practitioners are not subject to such a restriction against solicitation. When they advertise that they will perform legal-type services, the

54 The attorney may be disclipined by the bar or the courts for betraying his client's confidences or interests, even though no fraud or neghigence is present. See, e.g., United States v. Costen, 38 Fed. 24 (C.C.D. Colo. 1889).

55 The attorney may be suspended or disbarred for misconduct which would not be discouraged by a private cause of action for the return of a small fee. See, e.g., Marsh v. State Bar of California, 210 Cal. 303, 291 Pac. 583 (1930).

56 See CaI. BUs. \& Prof. Code $\S 5100$. One authority has suggested that the Treasury Department should establish federal standards of training, experience and integrity for all persons who prepare federal tax returns, and that a person who prepares sucl tax returns should be held to professional standards of competency. See BITTKER 2-5.

57 See Barton v. State Bar of California, 209 Cal. 677, 682-83, 289 Pac. 818, 820 (1930). A.B.A. Canon 12, in part, provides: "In fixing fees it should never be forgotten that the profession is a brancl of the administration of justice and not a mere money-getting trade."

58 A.B.A. Canon 27, in part, provides: "It is unprofessional to solicit professional eniployinent by circulars, advertisements, through touters or by personal conmunications or interviews not warranted by personal relations ...." See Rule 2, Rules of Professional Conduct. A.B.A. Canon 46 allows a lawyer engaged in a specialized service to send a dignified notice of that fact to other lawyers.

50 See Hewitt, Advertising by Lawyers, 15 A.B.A.J. 116 (1928). 
public may be harmed or benefited depending upon the circumstances. For example, an accountant may utilize advertising to attract tax work which could be more adequately and inexpensively performed by a tax attorney. ${ }^{60} \mathrm{~A}$ lay practitioner sucl as a title insurance company, on the other hand, may, through advertising, make known and available to the public a valuable service at a cost far below that charged by attorneys. ${ }^{61}$ In many cases, responsible advertising by non-lawyer groups and corporations may aid laymen in recognizing when legal advice is necessary. ${ }^{62}$ There is a great difference, for example, between an attorney who sends a runner to the local hospital to solicit business and a labor union representative who informs a union member who has been injured on the job that he may seek the advice of the union attorney concerming recovery for his imjuries. In the former case, the conduct may be condemned because there is no assurance that a capable attorney will be employed; ${ }^{63}$ in the latter case the conduct should not be condemned because it may inform an otherwise ignorant person of his legal rights and will ensure that he receives effective counsel while seeking to recover a valid claim. Perhaps state and local bar associations should utilize advertising to solicit busmess that would otherwise go to lay practitioners, and to ensure that all persons are aware of their legal rights and have access to competent counsel.

\section{E. Expense of and Possibility of Access to Legal Advice}

When deciding whether to prohibit lay bodies from engaging in certain legal or semi-legal activities, the courts should consider carefully the alternatives remaining to members of the public who wish to have these services performed. A lay body may be able to perform these services for a low cost or, perhaps, free of charge in connection with other non-legal services. A real estate broker, for example, may prepare a deed of conveyance without charge, incident to bringing the buyer and seller together. If the usual attorney's fee for this service is too high ${ }^{64}$ and the

${ }^{60}$ Cases in which accountants have sued to recover fees for tax services indicate that they have charged excessively high fees for tax services of dubious value. See, e.g., Zelkin v. Caruso Discount Corp., 186 Cal. App. $2 \mathrm{~d}$ 802, 9 Cal. Rptr. 220 (1960); Agran v. Shapiro, 127 Cal. App. 2d Supp. 807, 273 P.2d 619 (1954).

61 See note 24 supra.

62 See Committee Report on Group Legal Services, 39 CAx. S.B.J. 639, 662-64 (1964).

${ }^{63}$ Empirical evidence indicates that lower-level, less competent attorneys are more apt to rely on chasers to bring in personal injury business, although nearly all personal injury lawyers pay for many referrals. See CARLIN, LAwXERS on THEIR OWN 80-91 (1962).

64 Often the state or local bar association will issue a list of recommended, minimum fees. A.B.A. Canon 12, in part, provides: "In fixing fees, lawyers should avoid charges which overestimate their advice and services, as well as those which undervalue them . . . .

"In determining the amount of the fee, it is proper to consider: (1) the time and 
broker is prohibited from performing it, the parties may attempt to prepare the deed themselves, without the aid of the broker's relatively sophisticated training and knowledge. ${ }^{65}$ In many cases, lay groups such as title insurance companies can reduce the cost of legal-type services because they handle a large volume of business and, through specialization, have become very efficient in the work they perform..$^{B B}$

A related problem that may arise when laymen are enjoined from performing legal services is that persons needing such services may not have convenient access to an attorney. The problem may occur, for example, when there is a dearth of lawyers in the area, ${ }^{67}$ when the person seeking the service is not acquainted with an attorney and hesitates to select one from the telephone directory, or when the person las a problem which should be handled by a specialist and there is no method of ascertaining which attorneys are especially competent to landle the problem. ${ }^{88}$ In contrast, non-lawyer groups are able to advertise their services; or the legal services they perforn may be closely connected with their normal busmess operations. Often these groups have their own attorneys to perform the legal services, which ehminates the problem of competency. The courts should hesitate to enjom lay persons from performing legal services when state or local bar associations have not

labor required, the novelty and difficulty of the questions involved and the skill requisite properly to conduct the cause; (2) whether the acceptance of employment in the particular case will preclude the lawyer's appearance for others in cases likely to arise out of the transaction, and in which there is a reasonable expectation that otherwise be would be employed ... ; (3) the customary charges of the Bar for similar services; (4) the amount involved in the controversy and the benefits resulting to the client from the services; (5) the contingency or the certainty of the compensation; and (6) the cliaracter of the employment, whether casual or for an established and constant client. No one of these considerations in itself is controlling. They are mere guides in ascertaining the real value of the service."

It is probable that in some instances lawyers have been given an exclusive hicense to - perform services in areas where a licensed attorney is not needed. For example, many attorneys charge exorbitant fees for handling routine divorce cases and simple probate matters. Cf. CarLDs, LawYERS on THEIr OWN 102 (1962); Schlossberg, Lawyers' Incomes and Professional Economics, 47 A.B.A.J. 968 (1961).

${ }^{65}$ See text accompanying notes 75-82 infra.

${ }^{6 B}$ Specialization will reduce the novelty of the issues and lead to repeat business. Among the factors which may properly be considered by an attorney in setting bis fee are the novelty of the questions involved and whether the employment is casual or for an established client. A.B.A. Canon 12, supra note 64 . See generally Commiltee Report on Group Legal Services, supra note 62, at 667-68, 709.

67 See, e.g., Conway-Brogue Realty Inv. Co. v. Denver Bar Ass'n, 135 Colo. 398, 415,312 P.2d 998, 1007 (1957).

68 The bar has been hesitant to allow attorneys to advertise specialized legal services. See Drinker, Legar Etrics 242-45 (1953); Commiltee Report on Group Legal Services, supra note 62 , at 710 . 
effectively advertised and adequately provided the services of competent attorneys at a reasonable price.

\section{II}

\section{LEGAL ACTIVITIES UNDERTAKEN BY LAYMEN}

\section{A. Real Estate Transactions}

Empirical studies have indicated that few people consult an attorney before buying or selling real estate, even though the transaction may be of great consequence in terms of money and legal complexity. ${ }^{69}$ In Cahiformia, for example, where thousands of homes are bought and sold each week, ${ }^{70}$ it has been estimated that only five real estate purchasers in one hundred consult a lawyer. ${ }^{71}$ Seldom do the trained officers of the title insurance companies discuss the transaction with the buyer, ${ }^{72}$ and in most cases where the purchaser takes a new mortgage from an institutional lender, he is represented by the mortgagee's attorney-a result of the buyer's willingness to turn the entire deal, including insurance and financing, over to the real estate broker. ${ }^{73}$ Thus for the most part, laynen, not lawyers, determine the title taken in real estate conveyances; whether there are immediately visible adverse results is debatable. ${ }^{74}$

69 See Caltforma Continumig Education of the Bar, Legat aspects of Reat Estate Transactions 3-4 (1956) [hereinafter cited as Legal Aspects of Rear Estate Transactrons]; Payne, 101 Home Buyers: The Consumer, The Conveyancing Process, and Some Questions of Professional Conduct, 16 ALA. L. Rev. 275, 281-93 (1964).

For an excellent description of the activities of Chicago attorneys in local real estate transactions, see CARInN, LaWXers on THEIR OWN 52-62 (1962). Interviews by the author indicate a keen competition for business between individual practitioners and both real estate brokers and savings and loan associations. Cf. Chicago Bar Ass'n v. Quinlan \& Tyson, Inc., 53 III. App. 2d 388, 203 N.E.2d 131 (1964), wherein Chicago attorneys gained a substantial victory over local realtors.

70 Because of the rapid rate of population growth in California, 4000 housing units are needed each week. Car. Senate Interiar Comar. on Subdrusion Developament \& Planning, 3 Appendix to Journat of tae Senate, Reg. Sess. 5 (1957). See generally Payne, supra note 69 , at 279 .

${ }^{71}$ See Griffith, Community Property in Joint Tenancy Form, 14 Stax. L. REv. 87, 89 \& n.7 (1961).

72 Ibid.

73 Payne, supra note 69, at 286-87. This survey indicated that in $83 \%$ of the cases where a new mortgage was given the vendee-mortgagor relied on the mortgagee's attorney.

${ }^{74}$ Compare the statement in Washington State Bar Ass'n v. Washington Ass'n of Realtors, 41 Wash. 2d 697, 699, 251 P.2d 619, 621 (1952). "The probability of injurious consequences from the acts of the unskilled, is shown by the constant stream of litigation arising from this source. These consequences are not made less probable nor are their results less severe, because the unskilled are not paid for their services," with the statement in State ex rel. Reynolds v. Dinger, 14 Wis. 2d 193, 205-06, 109 N.W.2d 685, 691 (1961), "The court's experience does not show us that the practice has outworn its usefulness, nor has danger and expense to the public in any substantial degree resulted from it." $C f$. Cowern 
The first question to ask concerning this situation is whether real estate brokers are qualified to handle such transactions. The degree of competency of a real estate broker will, of course, depend upon the area of the country in which he practices. Today most states require that brokers ineet certain educational and training requirements and pass an examination before they are hicensed to practice. In Cahifornia, for example, a Real Estate Commissioner has been appointed to regulate the issuance and revocation of real estate broker ${ }^{75}$ and salesman ${ }^{70}$ hicenses. ${ }^{77}$ To quahify, the broker must have held a salesman's hicense and actively engaged in the real estate business for two years, unless he has two years of real estate experience or has graduated from a four-year university course which included specialization in real estate. ${ }^{78}$ Moreover, the apphicant inust ineet certain standards of character and reputation ${ }^{70}$ and inust pass an examination which requires an understanding of the general legal effect of deeds and other legal instruments. ${ }^{80}$ The Commissioner inay conduct disciplinary proceedings and revoke the license of any broker who has engaged in misconduct. ${ }^{81}$

In refusing to enjoin real estate brokers from engaging in the legal aspects of real estate transactions, some courts have emphasized the importance of the safeguards provided by state hicensing requirements. ${ }^{82}$ Other courts have allowed laymen to supply simple factual information to deed forms because such an undertaking requires only ordinary intelligence rather than the skill peculiar to one trained and experienced in the law ${ }^{83}$ - the broker is acting as a mere scrivener rather than a legal consultant. ${ }^{84}$ The contrary argument is that a non-lawyer cannot distinguish between a simple and a complex instrument ${ }^{85}$ and that merely

v. Nelson, 207 Minn. 642, 647, 290 N.W. 795, 797 (1940). In LEGAL Aspects OF REAx Estate TrANSACrIONS 5-12, the numerous risks confronting the buyer and seller in a real estate transaction are listed.

75 "Real estate broker" is defined in CAx. Bus. \& Pror. CODE $§ 10131$.

76 "Real estate salesman" is defined in Cax. Bus. \& Prof. Code 810132.

77 See CaI. BUS. \& Pror. Code $\$ \$ 10050 ; 10071$.

78 See CaL. Bus. \& Pror. Code $\$ 10150.6$.

70 See Car. Bus. \& Prof. Code $\$ \$ 10150,10152$.

80 See Cal. Bus. \& Pror. Code § 10153.

81 See Cax. Bus. \& Pror. Code $\S \S 10175,10176$; Brown v. Savage, 240 A.C.A. 725, 49 Cal. Rptr. 901 (1966).

82 See, e.g., Creekmore v. Izard, 236 Ark. 558, 563-64, 367 S.W.2d 419, 422 (1963);

State ex rel. Indiana State Bar Ass'n v. Indiana Real Estate Ass'n, 244 Ind. 214, 222, 191 N.E.2d 711, 715-16 (1963).

${ }^{83}$ See, e.g., State Bar of Michigan v. Kupris, 366 Mich. 688, 116 N.W.2d 341 (1962); Cain v. Merchants Nat'l Bank \& Trust Co., 66 N.D. 746, 754-55, 268 N.W. 719, 723-24 (1936). 84 See People v. Sipper, 61 Cal. App. 2d. Supp. 844, 846-47, 142 P.2d 960, 962 (1943) (dictum).

${ }^{85}$ See People v. Title Guar. \& Trust Co., 227 N.Y. 366, 379, 125 N.E. 666, 670 (1919) (concurring opinion): "I am unable to rest any satisfactory test on the distinction between 
selecting a form requires a legal decision. A broker is not equipped to explain the legal effect of a form nor is he able to determine whether any legal problem exists. Furthermore, the type of conveyance and the title taken should be determined by the interests and needs of the parties and not by the business practice of the broker. ${ }^{86}$

In many cases, however, the conveyancing takes place in an escrow or title insurance company office which employs its own attorneys. ${ }^{87}$ Although these attorneys should be able to spot individual legal problems and select a deed suitable to the parties' needs, it is likely that the parties will already be bound by a "deposit receipt" which will designate the type of deed to be issued. ${ }^{88}$ Moreover, since these lawyers will be primarily concerned with the interests of the company rather than the needs of the parties, it is unlikely that the parties will receive adequate legal services.

Since the broker has a direct pecumiary interest in the outcome of the transactions between the buyer and the seller, the problem of conflicting interests may arise. Technically, the broker is entitled to his commission when he has found a buyer ready, willing and able to meet the seller's terms; ${ }^{89}$ but, as a practical matter, the broker will be anxious to have the parties sign a deposit receipt so that there will be no possibility of dispute about his commission..$^{90}$ Therefore, the broker will avoid issues which might upset the deal and thus he may act contrary to the interests of both buyer and seller. In addition, although the broker

simple and complex instruments. The most complex are simple to the skilled, and the simplest often trouble the inexperienced."

86 See State Bar of Arizona v. Arizona Land Title \& Trust Co., 90 Ariz. 76, 88-89, 366 P.2d 1, 10 (1961) ; Chicago Bar Ass'n v. Quinlan \& Tyson, Inc., 53 Til. App. 2d 388, 408-09, 203 N.E.2d 131, 141-42 (1964).

87 See, e.g., Bar Ass'n of Tennessee v. Union Planters Title Guar. Co., 46 Tenn. App. 100, 326 S.W.2d 767 (1959) (company may draft and execute instruments necessary to perfect title); Oregon State Bar v. Security Escrows, Inc., 233 Ore. 80, 377 P.2d 334 (1962) (company may act as scrivener).

$88 \mathrm{~A}$ deposit receipt is a binding contract between buyer and seller. Many buyers and sellers sign deposit receipts under an illusion that they can unilaterally change or add to the terms of the deposit receipt form. See Legal Aspects of Real Estate Transactions 63.

89 See Fox v. Ryan, 240 Tll. 391, 396, 88 N.E. 974, 976 (1909); LEGAL Aspects of Rear Estate Transactions 58-60.

90 When the buyer and seller sign a deposit receipt, the broker is assured of his commission. See Iegat Aspects of Reat Estate Transactions 65, 69-70. Compare Hulse v. Criger, 363 Mo. 26, 43, 247 S.W.2d 855, 860 (1952): "It is a matter of great importance to the broker to get an agreement in writing and then to close the transaction as promptly as possible, because as a matter of practice that is when he usually gets paid.".

In contrast, attorneys are paid for advice whether or not the deal is closed, thus adding to the trustworthiness and integrity of their advice. Since attorneys will not hesitate to advise against closing a real estate deal, realtors are understandably reluctant to suggest the need for an attorney's advice. 
will ordinarily be hired by either the buyer or seller, he will be representing both parties and he therefore will be representing parties with conflicting interests. The vendor will be interested in a contract of sale which will minimize his obligations and maximize his income; the vendee will be interested in a secure and umencumbered title at a low price. ${ }^{01}$ Many courts have considered these arguments important justifications for enjoining real estate brokers from preparing documents that fix legal rights. ${ }^{92}$

On the other hand, regulations in many states hold real estate brokers to high fiduciary standards and will not allow them to represent more than one party to a transaction without the knowledge or consent of all the parties. ${ }^{93}$ Since it is hikely that a broker would rather lose a commission than surrender his license, the importance of the factor of conflicting interests may be somewhat diminished in these jurisdictions.

Much of the real estate broker's success depends, of course, upon the effectiveness of his advertising. Ordinarily, however, the broker does not advertise that he will perform legal services, but only that he has real estate listed which he is authorized to sell. Thus there is no danger that he will stir up hitigation nor that he will create disrespect for the judicial process. The legal services performed are usually rendered without charge as an incident to and necessary concomitant of his business. ${ }^{94}$

91 See generally Legal Aspects of Reat Estate Transactions 5-12.

92 See, e.g., State Bar of Arizona v. Arizona Land Title \& Trust Co., 90 Ariz. 76, 88, 366 P.2d 1, 9 (1961); Chicago Bar Ass'n v. Quinlan \& Tyson, Inc., 53 Ill. App. 2d 388, 415, 203 N.E. 2 d 131, 144 (1964).

In 1962, the Arizona case was nullified by a constitutional amendment giving licensed real estate brokers acting as a broker for one of the parties to a transaction "the right to draft or fill out and complete, without charge, any and all instruments incident thereto including, but not limited to, prelininary purchase agreements and earnest money receipts, deeds, mortgages, leases, assignments, releases, contracts for sale of realty, and bills of sale." ArIz. Const. art. XXVI, \& 1, ARIz. Rev. Stat. ANn. (Supp. 1965). See generally Cedarquist, The 1962 Arizona Constitutional Amendment, UNAUTHORIzed PraCTICE NEws 252 (1962).

93 See, e.g., CaL. Bus. \& Prof. Code § 10176. Subsection (d) of this section provides that a real estate broker cannot act for more than one party in a transaction without the knowledge or consent of all the parties. A.B.A. Canon 6 requires that a lawyer obtain the express consent of the parties; but even when such consent may be obtained, the lawyer should refuse to represent more than one party and should urge the other party to obtain his own counsel. See Frorida Bar Contanumg Legal Education, Frorma Rear Property Practice \& 1.5 (1965).

04 See, e.g., Conway-Brogue Realty Inv. Co. v. Denver Bar Ass'n, 135 Colo. 398, 414, 312 P.2d 998, 1006 (1957): "We distinguish between that part of the public in quest of legal advice and services and out of which arises only the rclationship of attorney and client and those bent on buying, leasing or selling real estate or borrowing money thereon, and out of which arises the relationship of seller-broker, buyer-broker, lessee-broker, lessor-broker, lender-broker or borrower-broker." Compare ARIZ. CoNsT, art. XXVI, \& 1, Aruz. Rev. Stat. AnN. (Supp. 1965); Cowern v. Nelson, 207 Minn. 642, 647, 290 N.W. 795, 797 (1940) (statute); Hulse v. Criger, 363 Mo. 26, 44-45, 247 S.W.2d 855, 861 (1952). 
Moreover, many courts have recognized that the great expense and inconvenience of hiring a lawyer is not justified in view of the slight possibility of harm to the parties when a broker handles the entire transaction. ${ }^{95}$ This is especially true in areas where there are few attorneys and gaining access to professional services is difficult. ${ }^{96}$ Should the parties be unwilling or unable to contact a lawyer, the readily available knowledge and training of the broker should be utilized lest the relatively inept parties attempt to handle the transaction themselves.

In California, as in many states, most real estate transactions require title insurance. This service may be handled by the escrow agent or by a separate title insurance company. ${ }^{97}$ Since the title insurance company normally insures only that the buyer will receive an insurable title, whereas the buyer normally desires a marketable title, the attorney eniployed by the title conpany is serving persons with differing interests. Therefore, even though most title companies have a competent staff of attorneys, the cases generally have held that the company may only prepare abstracts of title and may specify the title requirements necessary to the issuance of insurance. They may not draft or prepare the instruments necessary to cure defects in title. This must be done by an independent attorney who is primarily responsible to the parties and not the title company. ${ }^{98}$

Title insurance companies, and other companies, perform a related service by providing mortgage financing. Apparently, the mortgagor

95 See Ingham County Bar Ass'n v. Walter Neller Co., 342 Mich. 214, 229, 69 N.W.2d 713, 720-21 (1955); Cowern v. Nelson, supra note 94, at 647, 290 N.W. at 797; State ex rel. Reynolds v. Dinger, 14 Wis. 2d 193, 205, 109 N.W.2d 685, 691 (1961).

In Cowern v. Nelson, suppra, the court stated: "We do not think the possible harm which might come to the public from the rare instances of defective conveyances in such transactions is sufficient to outweigh the great public inconvenience which would follow if it were necessary to call in a lawyer to draft these simple instruments." Cf. Creekmore v. Izard, 236 Ark. 558, 565, 367 S.W.2d 419, 423 (1963), allowing a broker, without charge and only in the course of business, to fill in any legal forms providing the chient has declined to hire a lawyer.

${ }^{86}$ See, e.g., Creekmore v. Izard, supra note 95, at 563, 367 S.W.2d at 422; ConwayBrogue Realty Inv. Co. v. Denver Bar Ass'n, 135 Colo. 398, 415, 312 P.2d 998, 1007 (1957).

97 See generally Legat Aspects of Reat Estate Transactions 89-139.

08 See, e.g., Beach Abstract \& Guaranty Co. v. Bar Ass'n of Arkansas, 230 Ark. 494, 326 S.W.2d 900 (1959); Title Guar. Co. v. Denver Bar Ass'n, 135 Colo. 423, 312 P.2d 1011 (1957); New Jersey State Bar Ass'n v. Northern New Jersey Mortgage Associates, 32 N.J. 430, 161 A.2d 257 (1960); Hexter Title \& Abstract Co. v. Grievance Comm'n, 142 Tex. 506, 179 S.W.2d 946 (1944). But see La Brum v. Commonwealth Title Co., 358 Pa. 239, 56 A.2d 246 (1948) (relying on statute).

In Cooperman v. West Coast Title Co., 75 So. 2d 818 (Fla. 1954), the court held that the title company might undertake those activities necessary to create an insurable title. If the purchaser wishes advice on the marketability of title he must see his own attorney. This procedure could confuse most unsophisticated buyers. 
need not be represented by his own attorney and the mortgagee can draft the mortgage instrument because he is a party to the transaction. ${ }^{00}$ Since the purchaser is interested in the immediate use of the property and the mortgagee is interested in a valuable security, the conflict of interests is obvious. For example, a zoning ordinance or a covenant restricting the use of the land may render the property worthless for the particular needs of the buyer but may increase its value as security. ${ }^{100}$ Moreover, the mortgagee may abuse his position by substantially increasing the buyer's closing costs. ${ }^{101}$ There is evidence to indicate that in many states the fees charged by these companies are exorbitant compared to the value of the services rendered to the buyer. ${ }^{102}$

The inadequacy of legal representation in day-to-day real estate transactions should justify some concern by the bar associations, the legislatures, and the courts. If the bar associations were willing to undertake an advertising campaign which would make the service known, perhaps lawyer reference or legal aid services could effectively supply this service to home buyers and sellers at a nominal charge.

\section{B. Tax Service}

Non-lawyers engage in tax practices in three general areas-in business-tax planning, in preparing tax returns, and in representing clients before state and federal administrative tax departments and tax courts. In undertaking these activities the lay practitioner may come in contact with legal as well as non-legal (business or accounting) questions. In determining whether the activities in question should be enjoined as the unauthorized practice of law, the courts must first determine whether the practitioner has been handling legal questions. ${ }^{103}$ Then the court must determine whether the activity has been authorized by the federal government and, if not, whether the danger to the public is serious enough to merit enjoining the conduct. It has been suggested, for example, that legal advice rendered at the tax planning stages may have more serious consequences than legal advice rendered in preparing tax forms because, in the former case, while there are a wide range of alternatives available, once the decision is made it is irrevocable, and the decision affects the chent's legal rights as to many third persons; whereas, in the latter case,

99 See, e.g., Title Guar. Co. v. Denver Bar Ass'n, supra note 98, at 428-29, 312 P.2d at 1014.

100 See generally Payne, supra note 69 , at 326-28.

${ }^{101}$ See, e.g., Kentucky State Bar Ass'n v. First Fed. Sav. \& Loan Ass'n, 342 S.W.2d 397, 399 (Ky. 1961).

102 See generally Payne, supra note 69 , at 327 n.39.

103 Compare Agran v. Shapiro, 127 Cal. App. 2d Supp. 807, 273 P.2d 619 (1954) with

Zelkin v. Caruso Discount Corp., 186 Cal. App. 2d 802, 9 Cal. Rptr. 220 (1960). 
the tax form offers a limited choice of alternatives, the taxpayer may obtain a refund if a mistake is made, and the decision affects the chent's rights only in relation to the Treasury Department. ${ }^{104}$

In cases involving federal tax practice, the state courts probably cannot enjoin the activities of a lay practitioner who lias been authorized by the Treasury Department to practice before the Internal Revenue Service, ${ }^{105}$ provided the activities are directly connected with representing the taxpayer before the IRS. ${ }^{108}$ Licensing requirements and regulation of conduct in this area are left to the Treasury Department.

In all other situations, the courts should consider the competency of the person rendering the service in relation to the difficulty of the activities undertaken. An initial distinction should therefore be made between certified public accountants and other laymen. In all states an applicant must pass a uniform examination to qualify as a CPA. ${ }^{107}$ Many states have education and training requirements as well, ${ }^{108}$ indicating that CPA's are better qualified than other laymen to handle tax matters. The Cahfornia cases, ${ }^{100}$ for example, have allowed CPA's to prepare tax

104 See BITTRER 52-65.

105 Cf. Sperry v. Florida, 373 U.S. 37.9 (1963), holding that a non-lawyer permitted by the Secretary of Commerce to practice before the United States Patent Office cannot be restricted by a state bar association from performing tasks which are incidental to the preparation and prosecution of patent applications before the patent office.

Under Treasury Department Circular 230, 31 C.F.R. §§ 10-10.94 (1965), the United States Treasury Department enrolls lawyers, accountants, and laymen to practice before the Department and in the tax courts. An unenrolled person who has prepared a return for another may appear before the Department with respect to the tax liability covered by that return. 31 C.F.R. $\$ \S 10.7$ (a) (7), (b) (1965).

It is probable that Sperry v. Florida, supra, is applicable to persons enrolled by the Treasury Department even though 31 C.F.R. \& 10.39 (1965) provides that "nothing in the regulations in this part shall be construed as authorizing persons not members of the bar to practice law." This proviso most likely applies only to activities other than practice before the IRS. But see Agran v. Shapiro, 127 Cal. App. 2d Supp. 807, 824-25, 273 P.2d 619, 630 (1954). See generally vom Baur, Administrative Agencies and Unauthorized Practice of Law, 48 A.B.A.J. 715 (1962).

108 See BITTKER $6 \%$.

107 See Jennings, Common Interests of Lawyers \& Certified Public Accountants, 36 U. DEx. L.J. 399, 402 (1959); Summerfeld \& Ritzwoller, Income Taxes on the CPA Exam: What Role Do They Play?, 23 J. Taxation 54 (1965).

108 See, e.g., Cax. Bus. \& Prof. Code \$§ 5081-83.

109 See Zelkin v. Caruso Discount Corp., 186 Cal. App. 2d 802, 9 Cal. Rptr. 220 (1960); Agran v. Shapiro, 127 Cal. App. 2d Supp. 807, 273 P.2d 619 (1954). In the Agran case, the court found there was unauthorized practice of law and demied recovery of fees for services rendered by a CPA in preparing applications for loss carryback adjustments and the refund of taxes paid in prior years. The accountant was also unable to recover fees for the preparation of tax returns claiming a net operating loss carryover deduction, and for representation of the taxpayer before the tax authorities in resisting claims that the loss was not a net operating loss within the terms of the statute. There was no dispute concerning the fact of the loss, but merely a question of the effect of the law on this loss. 
returns for others where no substantial question of law arises and to represent a client in negotiations before the tax authorities provided there are no legal issues involved. ${ }^{110}$ In contrast, a New York court ${ }^{111}$ has indicated that it will not enjoin accountants from handling questions of law which are incidental to and arise in connection with the auditing of books or the preparing of tax returns, even though the character of the work is identical with prohibited activities done apart from bookkeeping or preparation of returns.

In an area involving statutes, regulations, and legal questions as complex as those in the tax field, there is good reason to restrict the activities of CPA's to accounting questions. It is likely that the nonlawyer would be unable to spot many subtle legal questions associated with tax work, yet there is considerable evidence that many accountants are handling tax planning problems that include legal questions, often to the detriment of their clients. ${ }^{112}$ Moreover, since many tax cases are decided on legal principles unrelated to tax law, it has been suggested that an attorney can more adequately represent his client before the tax authorities. ${ }^{113}$ In any event, there is no evidence that accountants

Notice the effect the doctrine in Sperry v. Florida, 373 U.S. 379 (1963), may have on Agran as to representations before the Treasury Department by an enrolled practitioner.

In Zelkin v. Caruso Discount Corp., supra, a CPA (law school graduate but not a member of the bar) was allowed to recover a $\$ 19,500$ balance on a $\$ 32,500$ contract whereby he agreed to represent a taxpayer before the Treasury Department concerning a deficiency based upon the amount of reserve the taxpayer could legitimately withold as security for conditional sales contracts. The CPA testified that he did not research points of law nor cite cases of law to the IRS agent. The court found that there was no unauthorized practice of law because it could not be said that no discussion of the problem would be possible without reference to legal issues.

110 The Joint Statement of Principles Relating to Practice in the Field of Federal Income Taxation, approved in 1951 by the American Bar Association and the American Institute of Accountants, is in accord with the California cases. As to the preparation of federal income tax returns, the Principles provide: "When a certified public accountant prepares a return in which questions of law arise, he should advise the taxpayer to enlist the assistance of a lawyer." As to the ascertainment of probable tax effects of transactions, they provide: "When such ascertainment raises uncertainties as to the interpretation of law (as to tax law and general law), or uncertainties as to the application of law to tho transaction involved, the certified public accountant should advise the taxpayer to enlist the services of a lawyer." See 3 MartandaIe \& HubBerd, Directory 189A (1966); 37 A.B.A.J. 537 (1951).

111 In re Bercu, 273 App. Div. 524, 78 N.Y.S.2d 209 (1948), aff'd, 299 N.Y. 728, 87 N.E.2d 451 (1949) (dictum).

112 Several examples are given in BrTTKER 57-65. In Bancroft v. Indemnity Ins. Co., 203 F. Supp. 49, 56 (W.D. La. 1962), the court took judicial notice of the fact that accountants regularly give legal advice in their income tax practice. In Bancroft, the accountant erroneously instructed the taxpayer that he could sell certain stock without income tax consequences.

113 See BrTrker 38-40, wherein the author cites three recent tax cases decided on grounds unrelated to tax law. These cases are Whipple v. Commissioner, 373 U.S. 193 
benefit the public by providing services at rates below those charged by lawyers. ${ }^{114}$

On the other hand, it is likely that the average accountant is better qualified to handle legal tax problems than is the general practitioner attorney, and, since tax attorneys are not allowed to make their specialty know to the public through advertising, it is arguable that the public would not be benefited by restrictions on accountant's activities. ${ }^{115}$ The argument for permitting accountants to handle legal tax problems becomes even more persuasive when it is realized that most states have legislation which subjects accountants to high fiduciary standards and to disciplinary proceedings for misconduct. ${ }^{116}$ Moreover, accountants tend to have a continuing relationship with their clients and, therefore, they may act as troubleslooters and eliminate tax problems before they begin. ${ }^{117}$

It should be remembered, however, that the primary obligation of an accountant is not to his client, but to members of the public who may rely on his financial statements. ${ }^{118}$ This conflict of interests may hinder his effectiveness as a tax practitioner. Furthermore, unlike the attorney, the accountant is not subject to an ethical mandate agamst voluntary disclosure of confidential information, nor is there an evidentiary privilege against compulsory disclosure of such information, ${ }^{119}$ although it has been suggested ${ }^{120}$ that all tax practitioners, lay and attorney, who have been admitted to practice before the Treasury Department are en-

(1963); Tellier v. Commissioner, 342 F.2d 690 (2d Cir. 1965); Fogel v. Commissioner, 203 F.2d 347 (5th Cir. 1953).

114 See note 60 supra.

115 See BITTKER 37. Unfortunately, a person is not allowed to practice both as an attorney and as a CPA. For critical analyses of this restriction see Wilson, The AttorneyC.P.A. and the Dual Practice Problem, 36 U. DET. L.J. 457 (1959); Comment, 3 U.C.L.A.L. REv. 360 (1956).

116 See, e.g., CaL. Bus. \& Pror. Code $\$ 5100$.

${ }^{117}$ See Brown, Accountant as Problem-Discoverer, 1958 So. CAI. TAx INst. 27; Jennings, supra note 107, at 404-05.

${ }^{118}$ See Johnson, Does the Tax Practitioner Owe a Dual Responsibility to His Client and to the Government? - The Theory, 1963 So. CAL. TAX INST. 25, 33-35.

119 See, e.g., Falsone v. United States, 205 F.2d 734 (5th Cir. 1953); Himmelfarb v. United States, 175 F.2d 924, 938-39 (9th Cir. 1949). Communications between accountants and their clients are privileged in a dozen states. See Note, 32 TEx. L. REv. 453 (1954). In Illinois, for example, a public accountant cannot be required to divulge information obtained by him in his confidential capacity as a public accountant. Irr. REv. Star. cli. $1101 / 2, \S 51$ (1957). An Tlinois federal court lias enforced the privilege where a deposition of an Hllinois CPA was to be used in a case in a Florida federal court. Palmer v. Fisher, 228 F.2d 603, 607 (7th Cir. 1955). It appears that federal courts inust follow state privilege rules in state law cases. See Degnan, The Law of Federal Evidence Reform, 76 Harv. L. REv. 275, 300-01 (1962); Comment, 52 CAITr. L. REv. 640, 646-48 (1964).

120 See BITTKER 48-50. 
titled to this evidentiary privilege. By admitting laymen to practice, the Department has invited taxpayers to rely on all these practitioners without discrimination, and a Department circular provides that all laymen enrolled before the Internal Revenue Service shall have the same privileges as enrolled attorneys. ${ }^{121}$

Since persons who are not CPA's or lawyers have hittle competence in handling difficult tax problems, their activities in this area should be regulated and restricted. ${ }^{122} \mathrm{~A}$ blanket prohibition against preparation of tax returns by laymen inay be undesirable, however, for laymen who are experienced in preparing standard tax forms can provide a low-cost service to wage earners who are unable or unwilling to undertake the routine clerical task of completing a standard income tax forn themselves. ${ }^{123}$ On the other hand, the public is not benefited when persons

12131 CF.R. $\$ 10.39$ (1965).

122 CAI. BUS. \& PROF. CODE $\S \S 5050-52$ apparently restricts the preparation of tax returns to licensed accountants or attorneys, unless the services performed are only routine and clerical. 10 Ops. CAr. ATT'Y GeN. 41 (1947). See generally Brtrzer 4-5.

${ }^{123}$ See, e.g., Lowell Bar Ass'n v. Loeb, 315 Mass. 176, 52 N.E.2d 27 (1943). Recent statutes lad required income tax returns from many wage earners previously exempt. A tax service was established by the wife of an attorney and was staffed by personnel who were neither accountants nor lawyers, except for the general manager who was an accountant. About 100 persons were employed; its customers were exclusively persons whose income consisted of salary or wages. Prices ranged from $\$ 2$ to $\$ 3.75$ per person; there was extensive advertising. The court enjoined the service from advertising that legal counsel would be provided in proceedings before the tax authorities; but the court allowed the service to continue preparing simple tax returns. The court expressly refused to decide whether filling in returns more complicated than those in question would constitute the unauthorized practice of law.

There is substantial evidence that persons who are neither lawyers nor CPAs are not qualified to prepare even the simplest tax forms. For example, in order to determine low smart the tax "experts" are, a newspaper reporter had his tax return prepared by seven different people in the business-real estate dealers and salesmen, insurance agents, public accountants, and a chain organization. At each place he made available the same information: a W-2 form that said he received about $\$ 9,000$ and two sheets of paper listing income from dividends and rent and amounts paid for medical expenses, drugs, property taxes, interest on a mortgage, union dues, business activities, gasoline, and charitable contributions. The fees charged for the tax service ranged from $\$ 5$ to $\$ 18.50$. All seven of the "experts" arrived at different results and all were incorrect. The calculations ranged from an $\$ 18$ deficiency to a $\$ 142$ refund. Oakland Tribune, March 6, 1966, p. 1, col. 1.

On the other land, some persons have received salisfactory service from chain taxservice organizations. In an interview, one individual, an insurance salesman, reported that be submitted his income statement and other relevant data to a nation-wide tax service. The organization itemized the deductions on a long-form, legitimately reducing taxes payable by over $\$ 150$ below the taxpaycr's calculations. The charge for the service was $\$ 17.50$. An experienced tax attorney could not profitably handle such a matter for less than $\$ 100$. Interview with Taxpayer in Berkeley, Calif., April, 1966. For practical suggestions on how a law office may be operated to compete with lay tax services, see Brown, Law Offices for Middle-Income Clients, 40 CAL. S.B.J. 720 (1965). 
who are not CPA's or attorneys undertake to solve legal questions of tax law. ${ }^{124}$ Perhaps the bar associations could solve this problem by providing an adequate lawyer reference service supported by an effective advertising campaign to make these specialized services known and available at a low cost to those who need them.

\section{Estate Planning}

Although less than two percent of the deaths in the United States lead to federal estate tax liability, ${ }^{125}$ estate planning has become a popular and lucrative practice, undertaken by both lawyers and laymen. ${ }^{128}$ Several reasons for the growth of this activity have been suggested: hife insurance companies desire to promote the sales of life insurance; many persons beheve their estates will be subject to taxation; it is easy to tell others what to do with their affairs; errors which are made will go uncorrected because the activities involve planning rather than litigation and there is, therefore, no lawyer on the other side; and specialization-everyone wants to be an "expert."127 Poor service by lawyers is probably responsible for the imcrease in lay activities in estate planning-lawyers who are specialists in this field are too expensive and too difficult to locate; general practitioners too often rely on plans which have been devised by insurance companies or on forms drafted by trust companies, and these practitioners are hesitant to suggest a specialist because they do not want to lose the fee. ${ }^{128}$

124 See, e.g., Gardner v. Conway, 234 Minn. 468, 48 N.W.2d 788 (1951); Blair v. Motor Carriers Serv. Bureau, Inc., 40 Pa. D. \& C. 413, 430-31 (1939).

In the Gardner case, the local bar association committee on the unauthorized practice of law hired a private investigator to ask defendant, an advertised "income tax expert," to prepare his forms and, simultaneously, to submit various legal questions to the defendant and ask that they be solved in preparing the forms. The defendant rendered the services and the bar brought proceedings to enjoin this conduct.

In the Blair case, laymen operated a "Tax Service Company" which advised businessmen on methods of avoiding or reducing taxes. The corporation was enjoined from acting as tax consultants but was not prohibited from preparing and filing tax returns.

125 See Warren \& Surrex, Federal Estate and Gift Taxation $42-43$ (1961).

128 See generally Allison, Estate Planning: New Growth Industry, Fortune, March, 1956, p. 138.

127 See Trachtman, A Credo for Estate Lawyers, 27 UNAUthortzed Practice NEws, $357,360-61$ (1961).

$128 I d$. at 370-72. A New York tax attorney has said: "In failing to equip themselves for this sort of work, lawyers have not only abdicated a responsibility toward their chients, they have also overlooked a lucrative source of income." Allison, supra note 126, at 217.

Interviews with individual practitioners in Chicago indicate that some inexperienced attorneys rely entirely on a bank or trust company to draft a will for a client. So long as the bank or trust company is named as executor, it is willing to do the attorney's work at no cliarge. These companies probably do a better job than the attorney could have done. The attorney plays a secondary role, collecting a fee from his client for doing nothing. See Carin, Lawyers ON THEIR OWN 102 (1962). 
Non-lawyer estate planning activities fall into three categories: (1) services performed by trust companies and trust departments of banks; (2) services performed by life insurance salesmen; and (3) services performed by laymen who deal solely in estate planning activities. ${ }^{120}$ The types of activities performed by these practitioners at the planning stage involve either the drafting of legal instruments such as wills or trusts, or the rendition of legal advice such as the optimum methods of utilizing the marital deduction. ${ }^{130}$ Trust companies and insurance salesmen usually do not charge fees for their assistance, but perform the services incident to their normal business of fiduciary and salesman. The layman, on the other hand, charges a fee for his services since estate planning is his only business.

Since trust companies hire staffs of attorneys to handle the legal problems involved in their estate planning activities, there should be no question of competency involved if one of the attorneys rather than a lay employee renders the legal advice. On the other hand, when any employee of a trust company renders legal advice to a chent or potential client, serious problems of conflicting interests will arise. The estate planner will invariably suggest an arrangement whereby it will act as a fiduciary-executor or trustee-regardless of whether this is in the best interests of the client or whether a trust arrangement is the device best suited to the chent's needs. ${ }^{131}$ Moreover, in drafting the legal instruments, the fiduciary will desire terms giving it the broadest powers and the fewest responsibilities, whereas the interests of the client will generally dictate limited fiduciary powers and numerous fiduciary duties. ${ }^{132}$ Since trust companies may engage in unlimited advertising, the company least

120 See Ells, Estate Planning in the Light of Recent Decisions, 39 Fra. B.J. 1004, 1005 (1965).

130 Many cases have dealt with the right of an employee of a trust company to appear before the probate court in connection with the company's fiduciary duty to execute or carry out the terms of the will or trust. The cases are divided as to whether the trust company must hire an independent attorney. Compare Detroit Bar Ass'n v. Union Guardian Trust Co., 282 Mich. 707, 281 N.W. 432 (1937); Judd v. City Trust \& Sav. Bank, 133 Ohio St. 81, 93-94, 12 N.E.2d 288, 293-94 (1937) with Arkansas Bar Ass'n v. Union Nat'l Bank, 224 Ark. 48, 56-57, 273 S.W.2d 408, 411 (1954); State Bar Ass'n of Connecticut v. Connecticut Bank \& Trust Co., 145 Conn. 222, 236, 140 A.2d 863, 871 (1958). Since an attorney permanently employed by the trust company might be tempted to conceal a breach of fiduciary duty by his employer, the cases requiring the use of an independent attorney appear to take the best approach.

On the other hand, it can be argued that if attorneys are given an exclusive license to practice before probate courts, they may charge excessive fees for handling routine matters which fiduciaries can competently handle without extra charge.

131 See, e.g., Miller v. St. Louis Union Trust Co., 335 Mo. 845, 869-70, 74 S.W.2d $348,359-60$ (1934).

132 Ibid. 
capable as a fiduciary may attract the most customers through an effective advertismg campaign. ${ }^{133}$ In contrast, an attorney engaged in estate planning would be likely to recommend the most qualified fiduciary..$^{134}$ Perhaps the only argument in favor of allowing trust companies to render legal advice and draft imstruments is that they are readily available to the potential client and they do not charge a fee, at least until later when they undertake their duties as a fiduciary.

The cases dealing with the unauthorized practice of law by trust companies have held that fiduciaries can give prospective clients general information concerning the scope and effect of various laws mvolved in estate planning, describe generally the complexity of federal and state taxes and the means available to avoid them, and explain the advantages and disadvantages of the various means provided by law for the distribution of property; but they cannot give legal advice concerning the customer's particular circumstances or draft legal instruments, ${ }^{135}$ although some cases have made an exception for the drafting of simple, non-testamentary trust instruments. ${ }^{136}$

Undoubtedly, many insurance salesmen and other lay estate planners have acquired a working knowledge of the estate and gift tax statutory provisions, a knowledge perhaps more thorough than that of the average lawyer who handles few estate problems. ${ }^{137}$ But these lay practitioners are not subject to disciplinary proceedings for breach of a confidential relationship. They are hable to their customers only for fraud or nnisrepresentation. ${ }^{138}$ Furthermore, the customers of these practitioners are

133 For examples of advertisements which have been approved by the American Bar Association Committee on Unauthorized Practice of the Law, see 28 UNAUTHorIzed Practice News, 114-15, 208-10, 330-32, 441-43 (1962-63).

134 This statement assumes, of course, that the attorney is not receiving "kick-backs" from the trust company. For a discussion of the attorney's duty in this regard, see Cohen, Fiduciaries-Corporate and Lawyers, 7 Ind. L.J. 295, 306-08 (1932).

135 See, e.g., Arkansas Bar Ass'n v. Union Nat'I Bank, 224 Ark. 48, 56-57, 273 S.W.2d 408, 413 (1954); State Bar of California v. Massachusetts Hosp. Life Ins. Co., Super. Ct. of San Diego (1965), consent decree published in 40 CAL. S.B.J. 507 (1965); State Bar Ass'n of Connecticut v. Connecticut Bank \& Trust Co., 145 Conn. 222, 236, 140 A.2d 863, 871 (1958). Compare Statement of Principles Between Mass. Bar Ass'n \& Boston Banks, 31 Unadthorized Practice News, 1, 4-5 (1965).

136 See, e.g., Merrick v. Am. Sec. \& Trust Co., 107 F.2d 271, 277 (D.C. Cir. 1939), cert. denied, 308 U.S. 625 (1940); Detroit Bar Ass'n v. Union Guardian Trust Co., 282 Mich. 216, 228-29, 276 N.W. 365, 369 (1937).

137 In Kasper v. Kellar, 217 F.2d 744 (8th Cir. 1954), an attorney negligently drafted his own will so as to lose the marital deduction. On remand, however, the court generously constructed a theory which allowed the bequest to qualify for the deduction. Kellar v. Kasper, 138 F. Supp. 738 (W.D.S.D. 1956). Cf. Biakanja v. Irving, 49 Cal. 2d 647, 320 P.2d 16 (1958), where a beneficiary under a will was awarded damages against a notary public who had prepared the will but had failed to attest it properly.

138 See Anderson v. Knox, 29 7 F.2d 702 (9th Cir. 1961). 
not entitled to an exclusionary privilege for confidential information communicated during the tax planning stages. ${ }^{130}$ This may also be the case for the customers of an attorney in those states that have no attorneyclient privilege for communications indicating the testamentary intent of a deceased client with respect to his execution of a will or other writing. ${ }^{140}$

When rendering legal advice to prospective customers, life insurance salesmen have a conflict of interests-they are interested in setting up an estate plan with the maximum amount of life insurance regardless of the best interests of their client. ${ }^{141}$ Furthermore, there is no indication that other lay estate planners are rendering a public service by providing competent, low-cost service to the public; in fact, it appears that the opposite is true. ${ }^{142}$ For these reasons, the courts have not hesitated to enjoin life insurance salesmen and other lay practitioners from rendering advice that applies specific legal principles to the customer's particular situation. ${ }^{143}$ It is likely, however, that many of these activities go undetected, and to discourage them, local bar associations must do more than attack them in the courts. The bar must find some effective means of providing these services competently and at a low cost to all the members of the public.

\section{Group Legal Services}

Group legal services are legal services rendered by an attorney for a group of individuals in matters which affect the interests of the group as a whole, in inatters which are of general interest to the group but particularly affect an individual member, or in matters which are of no immediate concern to the group and ouly affect the interests of an individual member. ${ }^{144}$ These legal-service groups are organized for several

139 See note 48 supra.

140 See, e.g., CaL. Evidence Code $\$ 960$.

141 In Anderson v. Knox, 297 F.2d 702 (9th Cir. 1961), a life insurance agent sold a bank-financed insurance policy with a face amount of $\$ 100,000$ to a 36 -year-old purchaser whose income was around $\$ 10,000$ a year, representing that the plan was suitable for the needs of the purchaser and his family. To pay the first premium, the purchaser converted and pledged his existing life insurance policies. The purchaser soon found the plan to be disadvantageous and was forced to cancel his various insurance policies. He then sued the insurance agent for fraud and misrepresentation and was awarded compensatory damages of $\$ 13,000$, punitive damages of $\$ 10,000$, and $\$ 2,500$ for mental distress.

142 See 26 Unadthordzed Practice News, 160, 163 (1960), reprinting a complaint filed in the state court by the Utah State Bar, alleging that a layman who was holding himself out as a tax expert and estate planner earned a net income of nearly $\$ 50,000$ a year. His secretary would answer the telephone with the words, "law offices." See generally, Allison, supra note 126 .

143 See, e.g., Chicago Bar Ass'n v. Financial Planming, Superior Court of Cook County, IIl., Case No. 53-S 10001 (March 1, 1958), reprinted in 24 UNauthorized Practice News 29 (1958); Oregon State Bar v. John H. Miller \& Co., 235 Ore. 341, 385 P.2d 181 (1963). 144 See Committee Report on Group Legal Service, 39 CaI. S.B.J. 639, 665 (1964). 
reasons: (1) to inform the members of the group that they have legal rights and should seek the advice of an attorney; (2) to refer the member to an attorney of known competence; and (3) to reduce the cost of legal services by spreading the risk and increasing the volume of business. ${ }^{145}$ Examples of associations of special interest groups which have provided legal services to their members include automobile clubs, ${ }^{146}$ creditors' associations, ${ }^{147}$ real estate taxpayers, ${ }^{148}$ motion picture distributors, ${ }^{149}$ unions, ${ }^{150}$ and insurance compamies. ${ }^{151}$ These associations provide legal services only in particular areas of the law which affect all the members of the group. A related situation exists when an association

145 Id. at 643,667 .

146 See, e.g., People ex rel. Chicago Bar Ass'n v. Chicago Motor Club, 362 III. 50, 199 N.E. 1 (1935); In the Matter of Maclub of America, Inc., 295 Mass. 45, 3 N.E.2d 272 (1936); Rhode Island Bar Ass'n v. Automobile Serv. Ass'n, 55 R.I. 122, 179 Atl. 139 (1935). The clubs advertised and provided legal services in civil and criminal suits relating to automobile accidents and arrests. In all the cases cited, these activities were enjoined because the association retained control over the attorney and acted as an intermediary between the attorney and his client.

The State Bar of California has entered into an "agreement" or treaty with various automobile associations, restricting the legal practices of these associations in both civil and criminal matters. See 40 CAL. S.B.J. 618 (1965).

147 See, e.g., People v. Merchants' Protective Corp., 189 Cal. 531, 209 Pac. 363 (1922); Richmond Ass'n of Credit Men v. Bar Ass'n, 167 Va. 327, 189 S.E. 153 (1937); State v. Mercluants' Protective Corp., 105 Wash. 12, 177 Pac. 694 (1919). In all the cases cited, the activities were enjoined.

148 See, e.g., People ex rel. Courtney v. Ass'n of Real Estate Taxpayers, 354 III. 102, 187 N.E. 823 (1933). In this case, a corporation was organized to protect the property of real estate owners in Cook County from forfeiture and tax sales caused by the Great Depression. Twenty to thirty thousand persons became members at a fee of $\$ 15$ a year. The corporation brought suits in the names of individual members which would have cost an individual $\$ 200,000$. The Cook County Attorney was successful in his suit to enjoin these activities as the unauthorized practice of law-the corporation was acting as an intermediary between the lawyer and his client.

149 See, e.g., Vitaphone Corp. v. Hutchinson Amusement Co., 28 F. Supp. 526 (D. Mass. 1939). Here the court upheld the activities of a non-profit agency which investigated and enjoined copyright violations-the organization was merely protecting business interests. That this case was decided in a federal court may be a key factor which distinguishes it from the Courtney case cited in note 148 supra.

150 See, e.g., Brotherhood of R.R. Trainmen v. Virginia State Bar, 377 U.S. 1 (1964); Hildebrand v. State Bar, 36 Cal. 2d 504, 225 P.2d 508 (1950); In re Brotherhood of R.R. Trainmen, 13 Ill. 2d 391, 150 N.E.2d 163 (1958).

151 See Justice Traynor's dissent in Hildebrand v. State Bar, supra note 150, at 524, 225 P.2d at 520, stating the reasons why insurance compamies are excepted from the ethical rules against lay intermediaries: (1) insurance is socially desirable; (2) representation by company attorneys is usually adequate; (3) the interests of the insurance company and the chent ordinarily coincide; and (4) adjustunents can be made when the interests of the company and the insured conflict. See, e.g., OMorrow v. Borad, 27 Cal. 2d 794, 167 P.2d 483 (1946), holding that when two persons insured by the same company collide, the insurer has a pecumiary interest in conducting the bigation so that neither party would recover from the other, and, therefore, the insurer must pay the attorney fees incurred by the insured in hiring independent counsel. 
or corporation provides general legal aid on all matters as a fringe benefit to its members or employees, usually in matters which the average attorney would consider unprofitable. ${ }^{152}$

Despite the advantages offered by these group services-providing a ineans of recognizing legal problems, providing access to attorneys, and ensuring low-cost, coinpetent representation-state courts have often enjoined their activities because of the intervention of a lay body between the attorney and his chent and because of the danger of conflicting interests between the lay body and the client. Moreover, since there is no restriction against advertising by the lay agency, the agency may use this device to stir up litigation, or to make unsavory profits by soliciting business at the highest possible price and hiring lawyers at the lowest possible price without regard to their competence. ${ }^{163}$

The degree to which the lay body interferes with the direct relationship between the attorney and his client may vary, depending upon the circumstances. In some cases, for example, the association may limit its activities to informing an individual member that he has legal rights whicl may be vindicated and recommending that the member consult a certain attorney of known competence whose fees are reasonable. ${ }^{154}$ In sucl a case, the presence of a lay intermediary is of little importance because the attorney is not controlled by the association. In contrast, an association or corporation may employ or directly control the salaries and activities of its own attorneys who purport to represent the members of the association or the customers or employees of the corporation, or third parties unrelated to the association or corporation. ${ }^{165}$ Since the attorney's first duty would be to the lay intermediary and not to the client, these arrangements should usually be viewed with disfavor. They may serve a valuable function, however, when the interests and goals of the members and the intermediary are identical ${ }^{156}$ or when the arrangement adequately satisfies a need for legal assistance which would otherwise go unfulfilled. ${ }^{157}$ If such services are allowed, they should be subject

${ }^{152}$ Several such arrangements are being or have been employed in the state of California. See Committee Report on Group Legal Services, supra note 144, at 670-83.

153 See, e.g., State v. Merchants' Protective Corp., 105 Wash. 12, 177 Pac. 694 (1919). An annual fee of ten dollars per member was charged; the corporation retained nine dollars and one dollar went to the attorneys.

154 See, e.g., Brotherhood of R.R. Trainmen v. Virginia State Bar, 377 U.S. 1 (1964). 155 See, e.g., NAACP v. Button, 371 U.S. 415 (1963); People v. Merchants' Protective Corp., 189 Cal. 531, 209 Pac. 363 (1922); Committee Report on Group Legal Services, supra note 144, at 679-83.

156 See, e.g., NAACP v. Button, supra note 155; People ex rel. Courtney v. Ass'n of Real Estate Taxpayers, 354 Ill. 102, 187 N.E. 823 (1933); Vitaphone Corp. v. Hutchinson Amusement Co., 28 F. Supp. 526 (D. Mass. 1939). Perhaps the automobile cases, cited supra note 146 , can also be included in this category.

167 See Gunnels v. Atlanta Bar, 191 Ga. 366, 12 S.E.2d 602 (1940), in which the state 
to restrictions and controls ensuring that the interests of the client are not jeopardized..$^{158}$ Should there be a substantial danger of conflict between the interests of the client and the intermediary, as could be the case, for example, if an employer hired an attorney to represent his employees in their personal legal matters, ${ }^{159}$ the activities should be enjomed.

Recently, the United States Supreme Court confronted some of the ethical problems involved in group legal activities and held that some endeavors of certain non-profit associations are constitutionally protected by the first and fourteenth amendments against state interference. In $N A A C P$ v. Button, ${ }^{100}$ the Court upleld the activities of an organization that urged nembers and non-inembers to seek the services of attorneys retained and paid by the organization for the purpose of assisting Negroes to vindicate their constitutional right of equal treatment. The Court emplasized that the solicitation was not for private gain and there was no danger of conflicting interests because no monetary stakes were involved. ${ }^{101}$ In Brotherhood of R.R. Trainmen v. Virginia State Bar, ${ }^{162}$

court refused to enjoin the bar association from offering its services to borrowers of money at usurious rates to defend suits brought against them by their creditors. Compare Justice Traynor's discussion in Hildebrand v. State Bar, 36 Cal. 2d 504, 525-26, 225 P.2d 508, 521; Committee Report on Group Legal Services, supre note 144, at 727.

108 The California State Bar Committee on Group Legal Services has recommended the following safeguards: (1) bona fide group purpose other than providing legal services; (2) no group control over attorneys in areas usually reserved for the attorney or the client; (3) no kick-backs between any attorney and the association; (4) no representation when there are conflicting interests; (5) dignified advertising to the public limited to notice of availability of service, the names of the attorneys to be divulged only to members of the group. Committee Report on Group Legal Services, supra note 144, at 723-24.

159 For example, the employee could have a claim against the employer; or the employee could have a sizable claim against an insurer who also insures the employer-should the employee recover, the employer's rates could be increased.

100371 U.S. 415 (1963). The NAACP stafi members would pass out printed forms to be signed by persons at a group meeting. The forms authorized the association to represent the signer in a legal proceeding to achieve desegregation. There were instances when the forms did not mention the name of a particular attorney and in a few cases the persons who signed were unaware of what they had signed, apparently because of their own disinterest. The association retained its own staff of attorneys who were paid on a per diem basis.

101 The litigation in Button began in a federal district court which struck down several of the Virginia regulatious. NAACP v. Patty, 159 F. Supp. 503, 530-34 (E.D. Va. 1958). The United States Supreme Court reversed and remanded the case to the Virginia courts for state construction and interpretation of the regulations. Harrison v. NAACP, 360 U.S. 167 (1959). The Virginia Supreme Court of Appeals upheld the validity of one of the statutes and directed the NAACP to refrain from soliciting legal business. NAACP v. Harrison, 202 Va. 142, 116 S.E.2d 55 (1960). This decision was reversed in Button. See generally Note, 63 CoLUM. L. Rev. 1502 (1963); Note, 72 YAIE L.J. 1613 (1963).

162377 U.S. 1 (1964). The activities of the union were undertaken to prevent settlements with the railroad by persons who were ignorant of their legal rights, and to discourage union members from employing attorneys who clarged excessively high contingent feesi.e., in excess of $25 \%$. 
the Supreme Court upheld the activities of a union that referred union members or their families to specific attorneys when a member had been killed or injured on the job. The court pointed out that there was no lay intermediary - the attorneys were not hired or paid by the union-and that the solicitation was not undertaken to enrich the recommended attorneys, but to fulfill a legitimate union function of reducing accidents and ensuring recompense for injuries. ${ }^{163}$

The scope of these decisions and how far the Supreme Court will extend them in future cases is presently the subject of debate. The California State Bar Committee on Group Legal Services has recominended that, because of an existing and unfilled public need for legal services, group legal services should not be confined to particular types of associations or to non-profit associations, that there be no requirement of a common interest among the members, and that the association be permitted to pay the attorney's fees. ${ }^{164}$ Moreover, the committee recominended allowing the use of house counsel by any organization to handle the imdividual legal problems of its employees or members if this would make legal services available to those who would not otherwise seek or receive such services. ${ }^{165}$ The Board of Governors did not approve these recommendations, however, because it felt it was not yet apparent that the organized bar could not fulfill the need for legal services through neighborhood legal service centers and more efficient legal aid and lawyer reference services. ${ }^{166}$ Thus, before amending the Rules of Professional Conduct to permit lay intermediaries, the State Bar hopes to fulfill the public need for legal assistance through its own local groups. Perhaps, in extending or refusing to extend the scope of Button and Brotherhood of R.R. Trainmen, the United States Supreme Court will consider the extent to which the state bar associations are providing needed legal services for all citizens.

A related problem involves the duty of the bar to provide legal services to those who are unable to pay for a lawyer or those who have problems which the ordinary attorney would consider unprofitable to handle. If the bar associations are to assert the exclusive privilege of licensed attorneys to practice law, these associations nust also undertake to meet their responsibility of providing legal services to those who need them. ${ }^{107}$

163 For related cases, see note 150 supra.

164 See Committee Report on Group Legal Services, supra note 144, at 725-26. As an alternative, the Committee recommended a method of certifying group legal services which conforms to the requirements of an administrative agency. $I d$. at 733 .

105 Id. at 727.

166 See 40 Cal. S.B.J. 325 (1965); 31 Unadthordzed Practice News, 63 (1965).

${ }^{167}$ See Llewellyn, The Bar's Troubles, and Poultices-and Cures?, 5 Law \& Contzasp. Proв. 104, 127 (1938): ". . . to use the criminal law to hog business for the Bar without 
Empirical evidence indicates that in some areas of the country bar associations have made initial efforts in this direction by providing legal aid for indigents. ${ }^{168}$ But little has been done to effectively provide lowcost services to the lower and middle income groups who do not qualify for welfare service. ${ }^{169}$ Despite a rising need for legal services, these persons often hesitate to seek the aid of an attorney out of fear of excessive fees or ignorance of legal rights. The result is that either the need for legal aid goes unfulfilled or laymen perform the services. ${ }^{170}$

By providing group legal services to those who need them, the bar associations inay benefit their own members, the attorneys, as well as the public. Through its own organization, a state bar association can use group legal services to compete with laymen who have been encroaching upon the legal profession by performing legal or semi-legal activities such as real estate transactions, tax service, and estate planming. These encroachments are a product of social changes-more middle and lower income people are in need of specialized legal services at a low cost. ${ }^{171}$ These intrusions have been successful because laymen have used business techniques to improve efficiency and have utilized advertising to attract customers. The structure of the bar, meanwhile, has remained rigid, maintaining the respectable and expensive front of oak panelling

making provision for reasonable attention by the Bar, at a reasonable charge, . . . is to play not with fire, but with TNT."

168 The federal anti-poverty program is now providing substantial funds to pay for full-time, neighborhood attorneys in some areas where persons are unable to pay for legal services. Oakland Tribune, March 22, 1966, p. 29, col. 6. But see Carlin \& Howard, Legal Representation and Class Justice, 12 U.C.L.A.L. REv. 381, 407-23, wherein the authors estimate that only about $10 \%$ of the persons needing legal services actually receive such aid. ${ }^{169}$ See generally Carlin \& Howard, supra note 168; Cheatham, Availability of Legal Services: The Responsibility of the Individual Lawyer and of the Organized Bar, 12 U.C.L.A.L. REv. 438 (1965); Committee Report on Group Legal Services, supra note 144, at 652-59. In Cheatham, supra, at 444, the author argues persuasively that the primary responsibility for providing legal services to the needy belongs to the bar and not to the individual lawyer: "It is unfair to put" on any working group the burden of providing for the needy out of its stock and trade. No one would suggest that the individual grocer or builder should take the responsibility of providing food and shelter needed by the poor."

${ }^{170}$ A Califorma attorney suggested a practical plan for setting up a law office for middle-imcome groups. Through controlled advertising, increased efficiency, and specialization, the "middle-income" attorney can provide competent legal services and reap a profit comparable to other attorneys in large firms. Among other innovations, the plan calls for increased use of legal assistants-non-lawyers who have been trained to handle the factgathering process and routine administrative matters. This would leave the licensed attorneys more time to handle legal questions. See Brown, Law Offices for Middle-Income Clients, 40 CAL. S.B.J. 720 (1965). Such a law office would not only lower legal fees, it would also create a more satisfying practice for the attorneys involved. Individual practitioners in the Chicago area who presently handle legal problems for middle-income persons are frequently dissatisfied with the type of work they do and the amount of money they earn. See Carits, Lawyers on Thetr OWN 168-73 (1962).

171 See Llewellyn, supra note 168, at 112-13. 
while refusing to adjust to consumer needs. ${ }^{172}$ An obvious exception, of course, is the large partnership of legal specialists, but these associations cater to only one segment of society-businessmen. ${ }^{17 a}$ In order to meet the legal needs of the large mass of middle and lower income persons and keep that business within the profession, the bar must utilize business inethods-it must compete with laymen through mass advertising, and, through lawyer reference or legal aid agencies, it must provide low-cost, standardized services to a larger chentele. ${ }^{174}$

\section{CONCLUSTON}

Licensed attorneys practice under rigid ethical restraints imposed

172 Id. at 114-17.

173 In 1954, approximately one-half the total gross income of lawyers was received from individuals and the remainder for legal services performed for the business community. Since 1947, lawyers have relied inore and more on businesses rather than individuals for their income. Much of this new business has gone to the large law partnerships; statistics show that lawyers in firms of nine or nnore members receive on the average over five times as much income as those in individual practice. See Segal, $A$ New Look: The Economics of the Profession, 43 A.B.A.J. 789, 853-54 (1957). Moreover, the large law firms are able to reduce their overhead below that generally incurred by individual practitioners. See Smith, Overhead Expenses in Solo Practice and in Law Partnerships, Law Office Econ. \& Management, August, 1961, p. 5.

Most of the pressure to enjoin laymen from engaging in the practice of law comes from individual practitioners since they feel the competition from laymen most keenly.

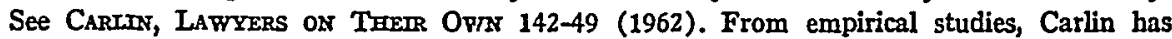
concluded that individual practitioners are usually dissatisfied with their practice: "One fact stands out clearly from this study of Chicago lawyers: the lawyer practicing by himself is generally at the bottom of the status ladder of the metropolitan bar. Although once held in the highest esteem as the modcl of a free, independent professional, today the individual practitioner of law, like the general practitioner in inedicine, is most likely to be found at the margin of his profession, enjoying httle freedom in choice of chents, type of work, or conditions or practice. . . Finding himself on the lowest rung of the status ladder of the profession, with little or no chance of lising, his practice restricted to the least remunerative and least desirable matters-to the dirty work of the profession, and beset by competition from lawyers and laymen alike, the individual practitioner is frequently a dissatisfied, disappointed, resentful, angry man. . . [T] individual practitioners place on being their own boss, combined with the conviction that they, unlike their colleagues in the big firms, are the real lawyers, may be viewed as an attempted inversion of the status hierarchy of the metropolitan bar, a device, in effect, for denying their patently low status." Id. at 206, 168, 200.

An individual practitioner in the state of New York disagrees with Carlin's conclusions: "The result of individual practice can be-and generally is-the development of a self-reliant, courageous, well-rounded lawyer, responsible for his own judgment, decisions and action. . . . Such men see life and the law as a whole, not just a segnent of it as a specialty. The broader a man's experience, the better his judgment should be .... Their love for the law is such that they want-passionately-to utilize to the maximum the talents and energies the Lord gave them. Such are the breed of law men who have built the foundations and structure of our liberties. ... The independent individual practitioner, whose voice is neither controlled by nor subservient to any particular elient or group of clients acts as a spokesman for various points of view." Gerhart, Practicing Law: The Case for the Individual Practitioner, 43 A.B.A.J. 793, 860, 857-58 (1957).

174 See Llewellyn, supre note 168 , at 125-26. 
by the courts, the state legislature, and the bar. Instituted and administered to protect the public and supported by a convincing rationale, these ethical standards provide some assurance to persons seeking legal advice that the attorney rendering the advice will be reasonably competent in handling the matter, that he will maintain the elements of the attorneyclient relationship and will not divulge confidential communications, and that le will be subject to disciplinary proceedings for misconduct.

Although not subject to these ethical standards, lay practitioners such as real estate brokers, accountants and estate planners are presently rendering specialized legal services to the public. For the most part, these practitioners fulfill a public need for low-cost legal assistance which has not been effectively provided by the bar. Rather than attempting to provide these services through licensed attorneys at a competitive price, local bar associations have attacked these lay activities in the courts as the unauthorized practice of law. The courts, often ignoring the public need for low-cost legal services, have usually supported the bar associations. Yet laymen continue to encroach into areas traditionally handled by licensed attorneys. Moreover, the United States Supreme Court las recently encouraged this intrusion by holding that some lay persons have a constitutional right collectively to provide themselves with adequate legal service, and by indicating that the courts should give hittle weight to state restrictions on the unauthorized practice of law when the local bar has not effectively provided the needed legal services.

Thus the national, state and local bar associations must compete with lay occupational groups to bring legal busmess back to licensed attorneys. These associations nuust find some means of competently providing low-cost legal assistance to everyone. As Professor Llewellyn said:

Real progress toward cure lies in group action to reorganize the getting of business and the doing of it in keeping with the age: in standardizing, spreading, and lowering the price of service. Once Service is sure, the Bar can outpublicize any lay competitor-wherever its Service can itself compete; but let Service fail, and the flank attack that opens can cripple and kill. ${ }^{175}$

Loyd P. Derby

175 Id. at 155. 